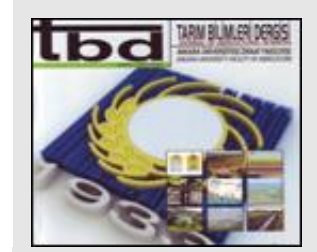

Tarım Bilimleri Dergisi Tar. Bil. Der.

Dergi web sayfasi:

www.agri.ankara.edu.tr/dergi
Journal of Agricultural Sciences

Journal homepage: www.agri.ankara.edu.tr/journal

\title{
The Effect of Nitrogen Deficiency on the Growth and Lipid Content of Isochrysis affinis galbana in Two Photobioreactor Systems (PBR): Tubular and Flat Panel
}

\author{
Leyla USLU ${ }^{\mathrm{a}}$, Oya IŞIK ${ }^{\mathrm{a}}$, Burcu AK ÇiMEN ${ }^{\mathrm{a}}$ \\ ${ }^{a}$ Cukurova University, Fisheries Faculty, Balcalı Campus, 01330, Adana, TURKEY
}

\author{
ARTICLE INFO \\ Research Article \\ Corresponding Author: Leyla USLU, E-mail: hizarcil@cu.edu.tr, Tel: +90 (506) 4567826 \\ Received: 14 February 2019, Received in Revised Form: 30 March 2019, Accepted: 09 April 2019
}

\section{AUTHORS ORCID ID:}

(Leyla USLU:0000-0002-9090-3240), (Oya IŞIK:0000-0001-7147-4252), (Burcu AK ÇİMEN:0000-0001-6508-5154)

\begin{abstract}
Energy is becoming one of the most expensive production inputs nowadays. Energy reserves are starting to run out and their polluting nature has become undeniable. Therefore, there is an urgent necessity for renewable energies. One of these energy sources is algae, which are seen as promising for biofuel production. Algae can be cultured in non-agricultural land, high photosynthetic activity, harvested throughout the year high biomass production. High lipid from algae is possible by reducing some elements of growth conditions from the nutrient medium. In this study,
\end{abstract}

Isochrysis affinis galbana species were cultured in two reactors; flat panel photobioreactors with different light paths $(1,3,5,7$ and 10 $\mathrm{cm})$ and tubular photobioreactors, with $50 \%$ nitrogen reduction and $20 \%$ inoculation densities. Biomass, lipid and protein ratios were determined. The highest lipid content of $33.13 \%$ was obtained from I. aff. galbana with $12.11 \%$ protein in flat panel photobioreactors with $50 \%$ nitrogen reduction and $10 \mathrm{~cm}$ light path, and a $0.991 \mathrm{~g} \mathrm{~L}^{-1}$ biomass rate was obtained. The highest optical density was found in the $10 \mathrm{~cm}$ light path flat panel photobioreactor with a $50 \%$ nitrogen reduction.

Keywords: Isochrysis affinis galbana; Photobioreactor; Lipid; N deficiency

(C) Ankara Üniversitesi Ziraat Fakültesi

\section{Introduction}

This study was conducted in order to determine the effects of $\mathrm{N}$ restriction on growth, lipid, protein, and chlorophyll contents in Isochrysis affinis galbana species of Prymnesiophyceae class and to produce renewable, non-toxic biofuels from microalgae.

Increasing interest in microalgae biotechnology in recent years is due to their high amounts of valuable bioactive metabolites (Becker 1994). In recent years, fat and fatty acid products obtained from single-celled algae have attracted considerable attention. Initially, the 'Solar Energy Research Institute' focused on the use of algal lipids as biofuels (Neenan et al 1986). Microalgae are potential sources of biodiesel with a lipid content of $20 \%$ to 50 , even $80 \%$ (Chisti 2007). Efforts are underway to exploit the use of renewable, non-toxic, biodiesel fuel from microalgae as an energy source. For this purpose, in addition to the identification of microalgae species with high lipid content and growth rate, studies on determination of serious stress conditions such as N limitation, P deficiency, Si deprivation, high salinity etc. have begun (Lynn et al 2000; Zhila et al 2005; Mandal \& Mallick 2009; Zhila et al 2011). Those stress conditions stimulate the increase of lipid content in the cell are being evaluated in many countries.

The purpose of the present study was to investigate the effect of $\mathrm{N}$ on the growth and lipid content of I. aff. galbana in two photobioreactor systems (PBR): tubular and flat panel. In addition, we investigated the maximum lipid and 
biomass in order to determine which PBRs are more suitable for culture of I. aff. galbana for biofuels production purpose.

\section{Material and Methods}

\subsection{Algae and culture conditions}

The microalgae I. aff. galbana UTEX LB 2307, was supplied by the University of Texas at Austin Collection, which is a single-celled marine species with two whips, with no haptonema and a single yellow-brown chloroplast. The cell size is 4-8 $\mu \mathrm{m}$ (Hoff 1987). The inoculum for the tubular and flat panel PBRs were grown under laboratory conditions on F/2 medium (Guillard et al 1973). Cells were cultured under a constant light intensity of $80 \mu \mathrm{mol}$ photonm ${ }^{-2} \mathrm{~s}^{-1}$ at $20{ }^{\circ} \mathrm{C}$ were used. The irradiation was measured using the Radiation Sensor LI-COR (LI-250, Inc. USA). The microalgae stock culture was cultured in an $8 \mathrm{~L}$ glass jar and air was continuously supplied. The volume of the tubular photobioreactor system is $110 \mathrm{~L}$. The tubular photobioreactor system was a horizontally installed reactor made of transparent acrylic tubes with an inner diameter of $2.6 \mathrm{~cm}$. In order to keep the craw flow rate constant, a flow rate of the circulation pump was set to $0.3 \mathrm{~m} \mathrm{~s}^{-1}$. A collection tank of about $150 \mathrm{~L}$ was built for the culture collection chamber. $\mathrm{CO}_{2}$ gas inlet flowmeter was provided. $\mathrm{pH}$ and temperature were measured continuously by probes. Outdoor flat panel PBRs were 10 $\mathrm{mm}$ thick transparent glass material, $50.0 \mathrm{~cm}$ wide and $50.0 \mathrm{~cm}$ high with $1,3,5,7$ and $10 \mathrm{~cm}$ light paths (Hu et al 1996a) in batch systems. The volumes of the PBR (without bubbling gas) was $2 \mathrm{~L}$ in $1 \mathrm{~cm}, 6 \mathrm{~L}$ in $3 \mathrm{~cm}, 10 \mathrm{~L}$ in $5 \mathrm{~cm}, 15$ $\mathrm{L}$ in $7 \mathrm{~cm}$ and $21 \mathrm{~L}$ in $10 \mathrm{~cm}$. The culture mixture was provided with $2 \% \mathrm{CO}_{2}$ enriched air as described by $\mathrm{Hu}$ et al (1996b). pH was arranged with a pH controller as 7 and light intensity was measured 3 times a day.

In the experiment, I. aff. galbana was cultured in different flat panel and tubular PBRs. Experimental work is carried out on $50 \% \mathrm{~N}$ deficiency according to $\mathrm{F} / 2$ medium and with inoculation densities of $20 \%$. All the applications were made in three replicates. The experiments were completed on different days and indicated in the tables.

\subsection{Analytical methods}

Chlorophyll $a$, total carotenoids, dry weight (biomass) and optical density (OD) analysis were performed daily. The dry weight was determined according to $\mathrm{Hu} \&$ Richmond (1994). The I. aff. galbana cell concentration was determined daily by measuring the optical density at $680 \mathrm{~nm}$ (Lin et al 2007), by a UV-visible spectrophotometer (Shimadzu, UV mini, 1240 model, Japan). Chlorophyll $a$ and total carotenoids contents were determined on a spectrophotometer at 665 , 645, 630 and $480 \mathrm{~nm}$ as described by Parsons \& Strickland (1963). All measurements were made in three replicates.

Microalgae were harvested for lipid and protein analysis in the stationary growth phase. I. aff. galbana cells were separated by centrifugation at $7500 \mathrm{rpm}$ for $10 \mathrm{~min}$, using the centrifuge model of Hereaus Supragufe 22. However, the biomass was dried at $55{ }^{\circ} \mathrm{C}$ for 2 hours, triturated with a grinder and then stored at $-20{ }^{\circ} \mathrm{C}$ for analysis. Lipid extraction from microalgae cells was performed by the method described by Bligh \& Dyer (1959). The total protein was calculated by the determination of $\mathrm{N}$ content (Nx6.25) according to Kjeldahl method (AOAC 1995).

\subsection{Statistical analysis}

The data were subjected to a one-way analysis of variance and Duncan's multiple range test was used as a post-hoc test. Statistical Package for the Social Sciences (SPSS) (Version 12.0, SPSS, Chicago, IL) (Zar 1999) was adapted to a personal computer. The differences were considered at a significance level of $\alpha=0.05$.

\section{Results and Discussion}

The measured temperatures were between $21.7^{\circ} \mathrm{C}$ and $24.7^{\circ} \mathrm{C}$ and light intensities were recorded between $224 \mu \mathrm{mol}$ photonm ${ }^{-2} \mathrm{~s}^{-1}$ and $284 \mu \mathrm{mol}$ photonm $\mathrm{m}^{-2} \mathrm{~s}^{-1}$ in culture at different light path lengths in flat PBR systems. In tubular photobioreactor systems, the temperature was determined between $21.6{ }^{\circ} \mathrm{C}$ and $22.3{ }^{\circ} \mathrm{C}$ and the light intensity between $281 \mu \mathrm{mol}$ photonm $\mathrm{s}^{-2}$ and $286 \mu \mathrm{mol}$ photonm $^{-2} \mathrm{~s}^{-1}$.

The biomass, protein, and lipid contents of I. aff. galbana were presented in Table 1 and Table 2 . In the control group and $\mathrm{N}$ deficiency group, the highest biomass was determined as 1.068 and $0.991 \mathrm{~g} \mathrm{~L}^{-1}$, respectively, in flat panel PBR with $10 \mathrm{~cm}$ light path. The highest amount of lipid was detected in the flat panel PBR with $10 \mathrm{~cm}$ light path where the highest biomass was obtained. The highest lipid in the control group was $15.19 \%$, while the N deficiency group was 
$33.13 \%$. The lowest amount of protein was obtained with $12.11 \%$ in the flat panel PBR with $10 \mathrm{~cm}$ light path where the highest lipid was obtained. The protein and total lipid ratios were similar in all control groups $(\mathrm{P}>0.05)$. In $\mathrm{N}$ deficient cultures, the lowest biomass and lowest lipid amount was obtained in the flat panel PBR with $1 \mathrm{~cm}$ and $3 \mathrm{~cm}$ light path.

Table 1- Main parameters of biomass, lipid and protein content of I. aff. galbana at control groups in flat panel PBRs and tubular PBR

\begin{tabular}{lccc}
\hline Reactors & $\begin{array}{c}\text { Biomass } \\
\left(\mathrm{g} \mathrm{L^{-1 }}\right)\end{array}$ & $\begin{array}{c}\text { Protein } \\
(\%)\end{array}$ & $\begin{array}{c}\text { Total lipid } \\
(\%)\end{array}$ \\
\hline Tubular PBR (16 days) & $0.902 \pm 0.02^{\mathrm{c}}$ & $28.65 \pm 10^{\mathrm{a}}$ & $15.09 \pm 0.70^{\mathrm{a}}$ \\
FP-PBRs $1 \mathrm{~cm}$ light path (15 days) & $0.801 \pm 0.02^{\mathrm{d}}$ & $28.67 \pm 0.60^{\mathrm{a}}$ & $15.31 \pm 0.30^{\mathrm{a}}$ \\
FP-PBRs $3 \mathrm{~cm}$ light path (16 days) & $0.813 \pm 0.03^{\mathrm{d}}$ & $28.80 \pm 0.50^{\mathrm{a}}$ & $14.98 \pm 0.50^{\mathrm{a}}$ \\
FP-PBRs $5 \mathrm{~cm}$ light path (16 days) & $0.893 \pm 0.02^{\mathrm{c}}$ & $28.83 \pm 0.20^{\mathrm{a}}$ & $15.07 \pm 0.60^{\mathrm{a}}$ \\
FP-PBRs 7 cm light path (18 days) & $0.958 \pm 0.01^{\mathrm{b}}$ & $28.65 \pm 0.60^{\mathrm{a}}$ & $15.12 \pm 0.60^{\mathrm{a}}$ \\
FP-PBRs 10 cm light path (19 days) & $1.068 \pm 0.02^{\mathrm{a}}$ & $28.80 \pm 0.50^{\mathrm{a}}$ & $15.19 \pm 0.70^{\mathrm{a}}$
\end{tabular}

Means values, $n=3$, different letters between the lines indicate significant difference at $5 \%$ by Duncan multiple range test

Table 2- Main parameters of biomass, lipid and protein content of $I$. aff. galbana at $\mathrm{N}$ deficiency groups in FP-PBRs and tubular PBR

\begin{tabular}{lccc}
\hline Reactors & $\begin{array}{c}\text { Biomass } \\
\left(\mathrm{g} \mathrm{L}^{-1}\right)\end{array}$ & $\begin{array}{c}\text { Protein } \\
(\%)\end{array}$ & $\begin{array}{c}\text { Total lipid } \\
(\%)\end{array}$ \\
\hline Tubular PBR (12 days) & $0.875 \pm 0.03^{\mathrm{bc}}$ & $13.50 \pm 0.70^{\mathrm{b}}$ & $32.10 \pm 0.40^{\mathrm{b}}$ \\
FP-PBRs 1 cm light path (11 days) & $0.772 \pm 0.01^{\mathrm{d}}$ & $15.05 \pm 0.50^{\mathrm{a}}$ & $30.01 \pm 0.10^{\mathrm{c}}$ \\
FP-PBRs 3 cm light path (13 days) & $0.785 \pm 0.01^{\mathrm{d}}$ & $15.01 \pm 0.40^{\mathrm{a}}$ & $30.16 \pm 0.30^{\mathrm{c}}$ \\
FP-PBRs 5 cm light path (13 days) & $0.832 \pm 0.02^{\mathrm{c}}$ & $13.07 \pm 0.20^{\mathrm{b}}$ & $32.09 \pm 0.80^{\mathrm{b}}$ \\
FP-PBRs 7 cm light path (14 days) & $0.913 \pm 0.01^{\mathrm{b}}$ & $13.02 \pm 0.40^{\mathrm{b}}$ & $32.18 \pm 0.50^{\mathrm{ab}}$ \\
FP-PBRs 10 cm light path (15 days) & $0.991 \pm 0.02^{\mathrm{a}}$ & $12.11 \pm 0.30^{\mathrm{c}}$ & $33.13 \pm 0.80^{\mathrm{a}}$ \\
\hline
\end{tabular}

Means values, $n=3$; different letters between the lines indicate significant difference at $5 \%$ by Duncan multiple range test.

Optical density, chl $a$ and total carotenoid amounts in the control and $\mathrm{N}$ deficiency groups were summarized in Table 3 and Table 4.

Table 3- Main parameters of optical density, chl $a$ and total carotenoid amounts of $I$. aff. galbana at control groups in flat panel PBRs and tubular PBR

\begin{tabular}{|c|c|c|c|}
\hline Reactors & $O D$ & $\begin{array}{c}\text { Chla } \\
\left(\mu g L^{-1}\right)\end{array}$ & $\begin{array}{c}\text { Total carotenoid } \\
\left(\mu g L^{-1}\right)\end{array}$ \\
\hline Tubular PBR (16 days) & $0.487 \pm 0.001^{\mathrm{c}}$ & $489 \pm 2^{\mathrm{a}}$ & $0.626 \pm 0.001^{\mathrm{a}}$ \\
\hline FP-PBRs $1 \mathrm{~cm}$ light path (15 days) & $0.457 \pm 0.010^{\mathrm{d}}$ & $358 \pm 5^{\mathrm{c}}$ & $0.408 \pm 0.002^{\mathrm{d}}$ \\
\hline FP-PBRs $3 \mathrm{~cm}$ light path (16 days) & $0.497 \pm 0.020^{\mathrm{c}}$ & $361 \pm 2^{\mathrm{c}}$ & $0.419 \pm 0.001^{\mathrm{d}}$ \\
\hline FP-PBRs $5 \mathrm{~cm}$ light path (16 days) & $0.568 \pm 0.001^{\mathrm{b}}$ & $422 \pm 6^{\mathrm{b}}$ & $0.459 \pm 0.002^{\mathrm{b}}$ \\
\hline FP-PBRs $7 \mathrm{~cm}$ light path (18 days) & $0.625 \pm 0.002^{\mathrm{a}}$ & $484 \pm 9^{\mathrm{a}}$ & $0.438 \pm 0.001^{\mathrm{c}}$ \\
\hline FP-PBRs $10 \mathrm{~cm}$ light path (19 days) & $0.588 \pm 0.010^{\mathrm{b}}$ & $501 \pm 10^{\mathrm{a}}$ & $0.467 \pm 0.001^{\mathrm{b}}$ \\
\hline
\end{tabular}

Means values, $n=3$; different letters between the lines indicate significant difference at $5 \%$ by Duncan multiple range test.

Table 4- Main parameters of optical density, chl $a$ and total carotenoid amounts of I. aff. galbana at $\mathrm{N}$ deficiency groups in flat panel PBRs and tubular PBR

\begin{tabular}{|c|c|c|c|}
\hline Reactors & $O D$ & $\begin{array}{l}\text { Chla } \\
\left(\mu g L^{-1}\right)\end{array}$ & $\begin{array}{c}\text { Total carotenoid } \\
\left(\mu g L^{-1}\right)\end{array}$ \\
\hline Tubular PBR (12 days) & $0.398 \pm 0.002^{\mathrm{c}}$ & $180 \pm 3^{a}$ & $0.810 \pm 0.001^{\mathrm{a}}$ \\
\hline FP-PBRs 3 cm light path (13 days) & $0.437 \pm 0.003^{\mathrm{b}}$ & $130 \pm 1^{\mathrm{b}}$ & $0.476 \pm 0.001^{\mathrm{c}}$ \\
\hline FP-PBRs $5 \mathrm{~cm}$ light path (13 days) & $0.441 \pm 0.001^{\mathrm{b}}$ & $172 \pm 1^{\mathrm{a}}$ & $0.543 \pm 0.002^{\mathrm{b}}$ \\
\hline FP-PBRs $10 \mathrm{~cm}$ light path (15 days) & $0.458 \pm 0.001^{\mathrm{a}}$ & $125 \pm 1^{\mathrm{b}}$ & $0.546 \pm 0.001^{b}$ \\
\hline
\end{tabular}

Means values, $n=3$; different letters between the lines indicate significant difference at $5 \%$ by Duncan multiple range test 
Initial optical density values were 0.263 for all groups. At the end of the experiment, the highest optical density value was be 0.625 in the flat panel PBR with $7 \mathrm{~cm}$ light path in the control group. The highest optical density was $0.458 \pm 0.001$ in the flat panel PBR with $10 \mathrm{~cm}$ light path in the $\mathrm{N}$ deficiency group. The minimum optical density was determined in the flat panel PBR with a $1 \mathrm{~cm}$ light path as $0.457 \pm 0.01$ and $0.301 \pm 0.001$ the control group and $\mathrm{N}$ deficiency, respectively.

The initial chl $a$ and total carotenoid were determined as $245 \pm 2 \mu \mathrm{g} \mathrm{L}^{-1}$ and $0.242 \pm 0.001 \mu \mathrm{g} \mathrm{L}^{-1}$ in the control group and in the $\mathrm{N}$ deficiency group, respectively. At the end of the experiment, the lowest chl $a$ was detected in the $\mathrm{N}$ deficient groups in flat panel PBRs with 1, 3,7 and $10 \mathrm{~cm}$ light path. But the highest total carotene was measured in the tubular PBR with $0.810 \mu \mathrm{g} \mathrm{L}^{-1}$ in the $\mathrm{N}$ deficient group. The lowest carotene in the group with $\mathrm{N}$ deficiency was determined in the flat panel PBR with $1 \mathrm{~cm}$ light path.

The primary objective of producing phototrophic organisms is to provide a continuous culture with optimal cell density. Algae requires that cultured cells constantly react to these conditions, as the various environmental factors during the cultivation of an algae show great changes both daily and seasonally. The biochemical composition of algal biomass is affected by environmental factors. The most important of these are growth conditions such as light, temperature, nutrient medium, salinity and pH (Brown et al 1989; Roessler 1990; Sukenik 1991; Cohen et al 1988; Lourenço et al 2002). Nutrient elements and their concentrations used in culture media with physical conditions may cause changes in microalgae growth and their biochemical structure. Growth affects concentrates as well as the nutrient content used in media (Brown et al 1989). Nitrogen (N) limitation has been shown to cause changes in the biochemical structure of many algal groups. Especially the increase in the amount of lipids (Illman et al 2000). For this purpose, in this study, $\mathrm{N}$ concentration in $\mathrm{F} / 2$ medium was reduced to fifty percent. It is known that different $\mathrm{N}$ levels can affect the biochemical composition and growth of microalgae (Fidalgo et al 1995; Xu et al 2001).

Microalgal biomass is very important for the study of lipid, and lipid is the main objective of increasing both simultaneously biomass. In this study, the reduction in the amount of $\mathrm{N}$ in the medium caused an increase in the amount of lipids in the cell and a decrease in the amount of protein. The highest biomass in the study was determined to be $0.991 \mathrm{~g} \mathrm{~g}^{-1}$ and the highest lipid was $33.13 \%$ with a $50 \% \mathrm{~N}$ deficiency in the flat panel PBR with $10 \mathrm{~cm}$ light path. However, the lowest amount of protein was found in this group. In another study, it was determined that low $\mathrm{N}$ concentration decreased the growth rate in $N$. oculata and did not affect growth rate in C. vulgaris (Converti et al 2009). In a research conducted by Xu et al (2001), Ellipsoidion sp. was cultured in different $\mathrm{N}$ sources and in a $\mathrm{N}$ free medium, the growth in the $\mathrm{N}$ free medium was low. Adenan et al (2016) reported that lipid ratio is increased in Chlorella and Chaetoceros species cultured with $\mathrm{N}$ deficiency applied to culture, but growth with protein and carbohydrate amounts decreases. The amount of biomass obtained due to the lipid content of the algae is also important. Biomass is generally reduced in cultures where $\mathrm{N}$ deficiency is applied. Thomas et al (1984) reported that $P$. tricornutum cultured in medium containing $\mathrm{N}$ and in the medium where $\mathrm{N}$ deficiencies were applied, and that the biomass amount was low in the nutrient medium where $\mathrm{N}$ deficiency was applied. Similar studies have suggested that the $\mathrm{N}$ restriction is responsible for the decrease in cell density and the decrease in biomass quantities in species (Kilham et al 1997; Pruvost et al 2009). In this study, the lowest biomass amount in I. aff. galbana was determined as $0.772 \mathrm{~g} \mathrm{~L}^{-1}$ in the flat panel PBR with $1 \mathrm{~cm}$ light pathway, in the $50 \% \mathrm{~N}$ (-) group with $30.01 \%$ lipid. $\mathrm{N}$ and $\mathrm{P}$ are the most essential elements for cell growth. These two elements are involved in the synthesis of intracellular structure. Therefore, cell growth instead of lipid synthesis will be dominant when these nutrients are present. Nitrogen deficiency limits algal growth and protein synthesis, resulting in increased lipid content (Converti et al 2009). In similar studies it was reported that the $\mathrm{N}$ limitation caused increases lipid; $D$. tertiolecta contained maximum total lipid in low $\mathrm{N}$ containing medium conditions (Fábregas et al 1989); P. tricornutum accumulates a high amount of total lipid in N deficiency (Thomas et al 1984); when the amount of $\mathrm{N}$ in I. galbana was increased from $0.04 \mathrm{mmol} \mathrm{L}^{-1}$ to $0.7 \mathrm{mmol} \mathrm{L}^{-1}$, the total lipid content decreased from $22 \%$ to $16.9 \%$ (Utting 1985). Tornabene et al (1983) reported that freshwater algae $N$. oloeabundas was cultured in growth medium with $\mathrm{N}$ deficiency at different rates, and the total fat percentage in $\mathrm{N}$ deficient groups varied between 35-54\% by dry weight. Ben-Amotz et al (1984) reported that different algal species were cultured in a nutrient-deprived medium and showed significant increases in total lipid content in all species. Sukenik \& Wahnon (1991) reported that when $I$. aff. galbana was cultured in a $\mathrm{N}$ deprived medium, both carbohydrate and total lipid ratios increase. Zhila et al (2005) reported that B. braunii was cultured in $75 \% \mathrm{~N}$ reduced medium and reported a $21 \%$ increase in total lipid. Weldy \& Huesemann (2007) reported that $D$. salina was cultured in a photobioreactor system with $\mathrm{N}$ deficiency and observed the change in total lipid ratio, which increased from $16 \%$ at the beginning of the stagnation phase to $44 \%$. In the study conducted by Rodolfi et al (2009), studied the dry matter and total lipid ratio of 4 species ( 2 marine and 2 freshwater species) by culturing them in a $20 \mathrm{~L}$ flat alveolar panel reactor with $\mathrm{N}$ deficiency. In the marine species, Nannochloropsis sp. a total lipid content of $60 \%$ was determined in N deprived medium. Gouveia et al (2009) found 
that the maximum total lipid ratio in $N$. oleabundans species was $56 \%$ when $\mathrm{N}$ restriction was applied for 6 days. Damiani Cecilia et al (2010) reported that when they cultured H. pluvialis under different stress conditions (high light and high light-nitrogen deficiency), the total lipid ratio increased from $15 \%$ to $32.99 \%$ in $\mathrm{N}$ deficiency and high light intensity. Bulut Mutlu et al (2011), in their study, cultured $C$. vulgaris for five in different nutrient media under laboratory conditions, they found that the highest total lipid content was $35.6 \%$ in the group with $100 \% \mathrm{~N}$ excision. In a study conducted by Uslu et al (2011), S. platensis increased total lipid (17.05\%) when cultured in a $100 \% \mathrm{~N}$ starvation medium. Uslu et al (2013), also investigated $C$. vulgaris in tubular photobioreactors in a $50 \%$ reduced $\mathrm{N}$ medium; lipid ratios were $12.34 \%$ and $38.16 \%$ for the control and $50 \% \mathrm{~N}$ limitation groups, respectively. In another research Uslu et al (2014) cultivated $P$. tricornutum with different light path lengths of 1, 3, 5, 7 and $10 \mathrm{~cm}$ and with a deficiency of $50 \% \mathrm{~N}$ in order to determine lipid, protein and biomass contents. The highest lipid, protein and biomass of P. tricornutum was $34.6 \%, 8.50 \%$ and $1.064 \mathrm{~g} \mathrm{~L}^{-1}$, respectively, in the flat panel PBR system with $7 \mathrm{~cm}$ light path. Ak et al (2015) studied P. tricornutum tubular reactor systems and in medium containing $50 \% \mathrm{~N}$, and found $35.04 \%$ lipid, $0.980 \pm 0.02 \mathrm{~g} \mathrm{~L}^{-1}$ biomass and $8.87 \%$ protein ratios. whereas $16.93 \%$ lipid, $1.036 \pm 0.025 \mathrm{~g} \mathrm{~L}^{-1}$ biomass and $31.05 \%$ protein were detected in the control group. Kamalanathan et al (2016) observed physiological changes on Chlamydomonas cultured in $\mathrm{N}$ and phosphorus (P) deficiency. They have reported that the physiology of Chlamydomonas reinhardtii, with $\mathrm{N}$ starvation and also with $\mathrm{N}$ plus $\mathrm{P}$ starvation combined, shows a deeper influence on the $\mathrm{P}$ starvation. At the same time, the photosynthetic performance of $C$. reinhardtii showed major changes under $\mathrm{N}$ starvation but was comparatively unchanged by $\mathrm{P}$ starvation. The lipid concentration per cell was at least 2.4 times higher in the $\mathrm{N}$ deficient groups than in the control group, however, the amount of protein is lower in groups with $\mathrm{N}$ deficiency. In general, $\mathrm{N}$ deficiency has a more dramatic effect on $C$. reinhardtii's physiology and lipids and protein levels than $\mathrm{P}$ deficiency.

In this study, similarly, the $\mathrm{N}$ limitation reduces the growth rate, which increases the cellular lipid rate. However, the amounts of biomass were not very low in groups with $\mathrm{N}$ deficiency. What is important is that the biomass ratio can be obtained at reasonable levels so that the increased lipid content can be economically assessed.

The algae biomass is affected by many parameters including the nutrient medium used for the culture of algae, the surface area and material of the system used, and the path taken by the light in the water column. Light is an important parameter especially in algal cultures. The angle at which the photobioreactor receives the light is important, in fact the surface area of the material plays a significant role in the efficiency to get enough light for the algal culture. According to Zijffers et al (2008), it is important for the reactor to take sunlight in the most efficient way. They generally recommend the use of flat and rectangular systems or linear and cylindrical shaped systems for good light energy distribution. Linear and cylindrical systems can be effective in focalizing light (Richmond 1986; Zou \& Richmond 1999; Durmaz \& Erbil 2017). In the study of Durmaz (2000), he investigated the growth of Chlorella sp. in natural light/dark periods outside the laboratory in reactors with different light path lengths $(10 \mathrm{~cm}, 15 \mathrm{~cm}$ and $20 \mathrm{~cm})$. Chlorella sp. reached the highest concentration of cells density of $49.5 \times 10^{6} \mathrm{~mL}^{-1}$ in the photobioreactors with $20 \mathrm{~cm}$ light path. While, the highest cells density was $49 \times 10^{6}$ cells $\mathrm{mL}^{-1}$ in the panels with $15 \mathrm{~cm}$ and $36.5 \times 10^{6}$ cells $\mathrm{mL}^{-1}$ in the panels of $10 \mathrm{~cm}$. In his study, it was stated that the length of light path should be adjusted according to the type of culture. It was determined that panels with $15 \mathrm{~cm}$ and $20 \mathrm{~cm}$ light paths have a high specific growth rate. It is emphasized that the sunlight intensity and duration is important in microalgae culture which is made in glass panels with different light path lengths and it is stated that the appropriate light path length for the species is important for efficiency. In this study, it was also determined that the growth increased as light path length increased.

In a study investigating the effects of $\mathrm{N}$ restriction on metabolites in microalgae cultures, an increase in the proportion of organic carbon compounds such as lipid was observed, while a decrease in cell number and chl $a$ was detected. However, yellowing of colors was observed in cultures due to increased carotene content (Shifrin \& Chisholm 1981; Sukenik et al 1989). Marín et al (1998) investigated the effects of D. salina on different N rates on carotene and chl $a$ amount. As the $\mathrm{N}$ deficiency increased, total carotene and chl $a$ decreased. In this study, chlorophyll content decreased in $50 \% \mathrm{~N} \mathrm{(-)} \mathrm{cultures} \mathrm{and} \mathrm{increases} \mathrm{in} \mathrm{total} \mathrm{carotene} \mathrm{content} \mathrm{occurred} \mathrm{in} \mathrm{I.} \mathrm{aff.} \mathrm{galbana.} \mathrm{The} \mathrm{highest} \mathrm{OD}$ values in I. aff. galbana was obtained in the control group and in the panel system with $7 \mathrm{~cm}$ light path. The lowest OD value was obtained in the group of $50 \% \mathrm{~N} \mathrm{(-)} \mathrm{in} \mathrm{the} \mathrm{tubular} \mathrm{photobioreactor} \mathrm{system} \mathrm{in} \mathrm{I.} \mathrm{aff.} \mathrm{galbana.} \mathrm{This} \mathrm{provides} \mathrm{us}$ with the result that the optical density is lower in the $\mathrm{N}$ deficiency groups, as in other parameters.

\section{Conclusions}

As a result, microalgae biomass can be used as an alternative source for the production of renewable energy. The studies on microalgae lipid production are mostly carried out under laboratory conditions. It is important to ensure the commercial production of microalgae. However, it is also significant to reduce the cost of culture to produce lipids. 
Finally, the results obtained in this study have shown that the lipid content of I. aff. galbana may be a good source of biodiesel. It would be more appropriate to use algae which can be cultured in nonagricultural lands for year-round instead of production of oil crops in agricultural lands as energy source.

\section{Acknowledgements}

Researchers would like to thank TUBİTAK (Turkey) for the financial support of the experiment (112Y016).

\section{References}

Adenan N S, Yusoff F M, Medipally S R \& Shariff M (2016). Enhancement of lipid production in two marine microalgae under different levels of nitrogen and phosphorus deficiency. Journal of Environmental Biology 37(4): 669-676

Ak B, Isik O, Uslu L \& Azgın C (2015). The effect of stress due to nitrogen limitation on lipid content of Phaeodactylum tricornutum (Bohlin) cultured outdoor in photobioreactor. Turkish Journal of Fisheries and Aquatic Sciences 15(3): 647-652

AOAC (1995). Official Methods of Analysis, 16. ed. In: Cuniff P (Ed). AOAC International, Washington Becker E W (1994). Microalgae: Biotechnology and Microbiology. Cambridge University Press, Cambridge, 291 pp

Ben-Amotz A, Tornabene T G \& Thomas W H (1984). Chemical profile of selected species of microalgae, with emphasis on lipids. Journal of Phycology 21(1): 72-81

Bligh E G \& Dyer W J (1959). A rapid method for total lipid extraction and purification. Canadian Journal of Biochemistry and Ahysiology 37(8): 911-917

Brown M R, Jeffry S W \& Garland C D (1989). Nutritional aspects of microalgae used in mariculture: a literature review. CSIRO Marine Laboratory Report, pp. 205-244

Bulut Mutlu Y, Isik O, Uslu L, Koç K \& Durmaz Y (2011). The effects of nitrogen and phosphorus deficiencies and nitrite addition on the lipid content of Chlorella vulgaris (Chlorophyceae). African Journal of Biotechnology 10(3): 453-456

Chisti Y (2007). Biodiesel from microalgae. Biotechnology Advances 25(3): 294-306

Cohen Z, Vonshak A \& Richmond A (1988). Effect of environmental conditions on fatty acid composition of the red alga Porphyridium cruentum: correlation to growth rate. Journal of Phycology 24(3): 328-332

Converti A, Casazza A A, Ortiz E Y, Perego P \& Del Borghi M (2009). Effect of temperature and nitrogen concentration on the growth and lipid content of Nannochloropsis oculata and Chlorella vulgaris for biodiesel production. Chemical Engineering and Processing: Process Intensification 48(6): 1146-1151

Damiani Cecilia M, Popovich C A, Constenla D \& Leonardi P I (2010). Lipid analysis in Haematococcus pluvialis to assess its potential use a biodiesel feedstock. Bioresource Technology 101(11): 3801-3807

Durmaz Y (2000). Chlorella sp' nin ince cam panel biyoreaktörlerde üretiminde 1şı̆̆ın etkisi üzerine bir araştırma. Yüksek lisans tezi, Ege Üniversitesi Fen Bilimleri Enstitüsü, (Yayınlandı) Bornova İzmir

Durmaz Y \& Erbil G Ç (2017). Performance of industrial-scale tubular photobioreactor in marine hatchery. Journal of Applied Phycolgy 29(6): 2755-2760

Fábregas J, Abalde J \& Herrero C (1989). Biochemical composition and growth of the marine microalga Dunaliella tertiolecta (butcher) with different ammonium nitrogen concentrations as chloride, sulphate, nitrate and carbonate. Aquaculture 83(3-4): 289-304

Fidalgo J P, Cid A, Abalde J \& Herrero C (1995). Culture of the marine diatom Phaeodactylum tricornutum with different nitrogen sources: Growth, nutrient conversion and biochemical composition. Cahiers de Biologie Marine 36: 165-73

Gouveia L, Marques Ae, Lopes Da Silva T \& Reis A (2009). Neochloris oleabundans UTEX\#1185: A suitable renewable lipid source for biofuel production. Journal of Industrial Microbiology \& Biotechnology 36(6): 821-826

Guillard R R (1973). Division Rates. In: Stein R J (Ed), Handbook of Hycological Methods, Culture Methods and Growth Measurement, Cambridge University Press, pp. 283-311 
Hoff F H \& Snell T W (1987). Plankton Culture Manual. Florida Aqua Farms, Dade City, 155 pp

Hu Q \& Richmond A (1994). Optimizing the population density in Isochrysis galbana grown outdoors in a glass column photobioreactor. Journal of Applied Phycology 6(4): 391-396

Hu Q, Guterman H \& Richmond A (1996a). A flat inclined modular photobioreactor for outdoor mass cultivation of photoautotrophs. Biotechnology and Bioengineering 51(1): 51-60

Hu Q, Guterman H \& Richmond A (1996b). Physiological characteristics of Spirulina platensis ～(cyanobacteria) cultured at ultrahigh cell densities. Journal of Phycology 32(6): 1066-1073

Illman A M, Scragg A H \& Shales S W (2000). Increase in Chlorella strains calorific values when grown in low nitrogen medium. Enzyme and Microbial Technology 27(8): 631-635

Kamalanathan M, Pierangelini, M, Shearman L A, Gleadow R \& Beardall J (2016). Impacts of nitrogen and phosphorus starvation on the physiology of Chlamydomonas reinhardtii. Journal of Applied Phycology 28(3): 1509-1520

Kilham S S, Kreeger D A, Goulden C A \& Lynn S G (1997). Effects of nutrient limitation on biochemical constituents of Ankistrodesmus falcatus. Freshwater Biology 38(3): 591-596

Lin Y H, Chang F L, Tsao C Y \& Leu J Y (2007). Influence of growth phase and nutrient source on fatty acid composition of Isochrysis galbana CMP1324 in a batch photoreactor. Biochemical Engineering Journal 37(2): 166-176

Lourenço S O, Barbarino E, De-Paula J C, Pereira L O S \& Marquez U M L (2002). Amino acid composition, protein content and calculation of nitrogen to protein conversion factors for 19 tropical seaweeds. Phycological Research 50(3): 233-241

Lynn S G, Kilham S S, Kreeger D A \& Interlandi S J (2000). Effect of nutrient availability on the biochemical and elemental stoichiometry in the freshwater diatom Stephanodiscus minutulus (Bacillariophyceae). Journal of Phycology 36(3): 510-522

Mandal S \& Mallick N (2009). Microalga Scenedesmus obliquus as a potential source for biodiesel production. Applied Microbiology and Biotechnology 84(2): 281-291

Marín N, Morales F, Lodeiros C \& Tamigneaux E (1998). Effect of nitrate concentration on growth and pigment synthesis of Dunaliella salina cultivated under low illumination and preadapted to different salinities. Journal of Phycology 10: 405-411

Neenan B, Feinberg D, Hill A, Mcintosh R \& Terry K (1986). Fuels from Microalgae: Technology Status, Potential, and Research Requirements. Publ. No. SERi/SP-231-2550, Solar Energy Research Institute, Golden CO

Parsons T R \& Strickland J D H (1963). Discussion of spectrophotometric determination of marine plant pigments, with revised equations for ascertaining chlorophylls and carotenoids. Journal of Marine Research 21: 115-163

Pruvost J, Van Vooren G, Cogne G \& Legrand J (2009). Investigation of biomass and lipids production with Neochloris oleoabundans in photobioreactor. Bioresource Technology 100(23): 5988-5995

Richmond A (1986). Handbook of Microalgal Mass Culture, FL: CRC Press, Boca Raton

Rodolfi L, Zittelli G C, Bassi N, Padovani G, Biondi N, Bonini G \& Tredici M R (2009). Microalgae for oil: Strain selection, induction of lipid synthesis and outdoor mass cultivation in a low-cost photobioreactor. Biotechnology and Bioengineering 102(1): 100-112

Roessler P G (1990). Environmental control of glycerolipid metabolism in microalgae: commercial implications and future research directions. Journal of Phycology 26: 393-399

Shifrin N S \& Chisholm S W (1981). Phytoplankton lipids: interspecific differences and effects of nitrate, silicate and light-dark cycles. Journal of Phycology 17(4): 374-384

Sukenik A (1991). Ecophysiological considerations in the optimization of eicosapentaenoic acid production by Nannochloropsis sp. (Eustigmatophyceae). Bioresource Technology 35(3): 263-269

Sukenik A \& Wahnon R (1991). Biochemical quality of marine unicellular algae with special emphasis on lipid composition, I. Isochrysis galbana. Aquaculture 97(1): 61-72

Sukenik A, Carmeli Y \& Berner T (1989). Regulation of fatty acid composition by irradiance level in the Eustigmatophyte Nannochloropsis sp. Journal of Phycology 25: 686-692 
Thomas W H, Seibert D L R, Alden M, Neori A \& Eldridge P (1984). Yields, photosynthetic efficiencies and proximate composition of dense marine microalgal cultures. I. Introduction and Phaeodactylum tricornutum experiments. Biomass 5(3): 181-209

Tornabene T G, Holzer G, Lien S \& Burris N (1983). Lipid composition of the nitrogen starved green alga Neochloris oleoabundans. Enzyme and Microbial Technology 5(6): 435-440

Uslu L, Isik O, Koç K \& Göksan T (2011). The effects of nitrogen deficiencies on the lipid contents of Spirulina platensis. African Journal of Biotechnology 10(3): 386-389

Uslu L, Durmaz Y, Isik O, Mutlu Y, Koc K \& Ak B (2013). Nitrogen limitation increases lipid content of Chlorella vulgaris at photobioreactor system. Journal of Animal and Veterinary Advances 12(1): 52-57

Uslu L, Ak B, Isik O \& Durmaz Y (2014). Effect of light path length and nitrogen deficiency on the biochemical composition of Phaeodactylum tricornutum. Fresenius Environmental Bulletin 23(6): 1309-1313

Utting S D (1985). Influence of nitrogen availability on the biochemical composition of three unicellular marine algae of commercial importance. Aquacultural Engineering 4(3): 175-190

Weldy C S \& Huesemann M (2007). Lipid production by Dunaliella salina in batch culture: Effects of nitrogen limitation and light intensity. Journal of Undergraduate Research 7(1): 115-122

Xu N, Zhang X, Fan X, Han L \& Zeng, C (2001). Effects of nitrogen source and concentration on growth rate and fatty acid composition of Ellipsoidion sp. (Eustigmatophyta). Journal of Applied Phycology 13(6): 463-469

Zar J H (1999). Biostatistical Analysis. Upper Saddle River. $4^{\text {th }}$ edn. Prentice Hall, New Jersey, Cap. 12, pp. 231-272

Zhila N O, Kalacheva G S \& Volova T G (2005). Effect of nitrogen limitation on the growth and lipid composition of the green alga Botryococcus braunii Kutz IPPAS H-252. Russian Journal of Plant Physiology 52(3): 311-319

Zhila N O, Kalacheva G S \& Volova T G (2011). Effect of salinity on the biochemical composition of the alga Botryococcus braunii Kütz IPPAS H-252. Journal of Applied Phycology 23(1): 47-52

Zijffers J W F, Janssen M, Tramper J \& Wijffels R H (2008). Design process of an area-efficient photobioreactor. Marine Biotechnology 10: 404-415

Zou N \& Richmond A (1999). Effect of light- path length in outdoor flate plate reactors on output rate of cell mass and of EPA in Nannochloropsis sp. Journal of Biotechnology 70: 351-356 